\title{
ZOONOTIC ENDOPARASITES IN DOGS FROM THE BOSNIAN-PODRINJE CANTON, BOSNIA AND HERZEGOVINA
}

Jasmin Omeragićc ${ }^{\text {, Davor Alagić }}{ }^{2}$, Sabina Šerić-Haračić ${ }^{3}$, Naida Kapo ${ }^{4}$, Darinka Klarić Soldo ${ }^{1}$, Emina Šabić, Ćazim Crnkićs ${ }^{1}$, Dženita Hadžijunuzović-Alagić ${ }^{6}$, Edin Aganović ${ }^{7}$, Vedad Škapur ${ }^{8}$

\author{
${ }^{1}$ Department of Parasitology and Invasive Diseases of Animals, Veterinary Faculty, \\ University of Sarajevo, Zmaja od Bosne 90, 71000 Sarajevo, Bosnia and Herzegovina \\ ${ }^{2}$ Department of Food Hygiene and Technology, Veterinary Faculty, University of \\ Sarajevo, Zmaja od Bosne 90, 71000 Sarajevo, Bosnia and Herzegovina \\ ${ }^{3}$ Department of Animal Health and Economics, Veterinary Faculty, University of \\ Sarajevo, Zmaja od Bosne 90, 71000 Sarajevo, Bosnia and Herzegovina \\ ${ }^{4}$ Department of Pharmacology and Toxicology, Veterinary Faculty, University of \\ Sarajevo, Zmaja od Bosne 90, 71000 Sarajevo, Bosnia and Herzegovina \\ ${ }^{5}$ Department of Feed and Animal Nutrition, Veterinary Faculty, University of Sarajevo, \\ Zmaja od Bosne 90, 71000 Sarajevo, Bosnia and Herzegovina \\ ${ }^{6}$ Clinics of Veterinary Faculty, University of Sarajevo, \\ Zmaja od Bosne 90, 71000 Sarajevo, Bosnia and Herzegovina \\ ${ }^{7}$ Government of the Bosnia-Podrinje Canton Goražde, \\ Maršala Tita 2, 73000 Goražde, Bosnia and Herzegovina \\ ${ }^{8}$ Institute of Animal Breeding, Faculty of Agriculture and Food Sciences, \\ University of Sarajevo, Zmaja od Bosne 8, 71000 Sarajevo, Bosnia and Herzegovina
}

Received 16 October 2020; Received in revised form 1 December 2020; Accepted 7 December 2020

\begin{abstract}
More than 30 dog parasite species have been identified in Bosnia and Herzegovina so far, and half of these are zoonotic. The aim of the study was to investigate the occurrence of parasitic infections in dogs from Bosnian-podrinje canton with a focus on zoonotic parasites. The study included 212 dogs (107 owned and 105 stray). One or more of the twenty parasite species were found in $82.55 \%$ of tested samples. Dicrocoelium dendriticum (Class Trematoda) was found in $0.94 \%$ of dogs. Dipylidium caninum and Mesocestoides lineatus (Class Cestoda) were found in $7.55 \%$ and $0.94 \%$ of dogs, respectively. Taenia spp. and Echinococcus spp. (Family Taeniidae) were found in $0.47 \%$ and $0.94 \%$ of samples, respectively. In the family of Nematoda, the following parasite species were identified with corresponding percent among tested dogs: Toxocara canis (25.94\%), Toxascaris leonine (8.96\%), Strongyloides stercoralis $(0.47 \%)$, Ancylostoma caninum (3.77\%), Uncinaria stenocephala (52.36\%), Trichuris vulpis (22.17\%), Eucoleus aerophilus (1.42\%), Dirofilaria immitis (1.89\%) and Dirofilaria repens $(1.42 \%)$. In the kingdom of Protozoa, the following parasite species were identified with corresponding percent among tested dogs: Cystoisospora canis (8.49\%), C. ohioensis (2.36\%), Cryptosporidium spp. (4.72\%), Sarcocystis spp. $(0.47 \%)$, Babesia spp. (5.19\%), and Giardia duodenalis (15.57\%). Leishmania infantum was not identified in tested samples. The results showed a high level of parasitic infestation in the dog population in the Bosnian-Podrinje canton, with a high occurrence of zoonotic parasites. Significant differences were found between owned and stray dogs for all classes of detected parasites with exception of the class Trematoda, disregarding specific parasite species.
\end{abstract}

Key words: Bosnian-Podrinje canton, dogs, endoparasites, zoonotic

\section{INTRODUCTION}

Being the most common animal species in urban areas, dogs are considered to be a

Corresponding author: Prof. Sabina Šerić Haračić, $\mathrm{PhD}$

E-mail address: sabina.seric-haracic@vfs.unsa.ba

Present address: Department of Animal Health and Economics,

Veterinary Faculty, University of Sarajevo, Zmaja od Bosne 90

71000 Sarajevo, Bosnia and Herzegovina

Phone: +38733663515

Copyright: (C) 2021 Omeragić J. This is an open-access article published under the terms of the Creative Commons Attribution License which permits unrestricted use, distribution, and reproduction in any medium, provided the original author and source are credited.

Competing Interests: The authors have declared that no competing interests exist. Available Online First: 18 February 2021

Published on: 15 March 2021

https://doi.org/10.2478/macvetrev-2021-0011 significant source for a large number of parasite species for humans, especially for children and immunocompromised individuals (1). Therefore, parasitological surveys are regularly conveyed worldwide $(1,2,3)$.

More than 30 dog parasite species have been identified so far in Bosnia and Herzegovina $(\mathrm{BiH})$, out of which more than half are zoonotic $(4,5,6$, $7,8)$. The reported frequency of infection varied from $36.11 \%$ to $99.06 \%$, while the number of identified parasite species was ranging between 8 and $19(4,5,6,7,8)$. Most of these parasitological 
studies were focused on the Sarajevo canton (the wider area around the country capital) and other major cities in the country. These urban areas have better infrastructure, education resources and more available funding for prevention and control compared to the semi-urban areas such as the Bosnian-Podrinje canton. Implementing an appropriate control and preventive program on certain geographical areas requires a parasitological survey. Therefore, we aimed to investigate dog parasitic infections in the Bosnian-Podrinje canton with particular emphasis on zoonotic parasites.

\section{MATERIAL AND METHODS}

During the first half of 2018, fecal, blood and serum samples were collected from 212 dogs of different breeds from the area of the Bosnian-Podrinje canton. Investigated dogs were categorized according to sex (113:99 male to female ratio), age (67 dogs $\leq 6$ months of age, and 145 dogs $\geq 6$ months), and ownership status (107 owned and 105 stray dogs). Stray dogs were sampled from the cantonal animal shelter in Gorazde.

Before sampling, each animal was clinically examined with a focus on clinical signs and changes that would be indicative of parasitic infection. Samples were taken regardless of clinical findings. Fresh fecal samples were conserved in 76\% alcohol solution. The fecal, blood and serum samples were refrigerated until testing. Samples from animals used in this study were collected using noninvasive methods and/or reused with consent, as samples collected with alternate purpose as regular diagnostic/screening procedures conducted by ordinating veterinarians.

Fecal samples were macroscopically checked for the presence of Echinococcus granulosus. Samples were tested for the presense of protozoal developing forms by flotation method (9) and by direct immunofluorescence test (MERIFLUOR $\mathbb{R}$ Cryptosporidium/Giardia test, Meridian Bioscience, Inc.), using a protocol previously described by Johnston et al. (10).

Blood samples were used for the detection of blood parasites by Giemsa staining of blood smears (9). Modified Knott's test was used for the detection of $D$. immitis and $D$. repens microfilaria.

Animal samples that were found positive for parasitic infection by either of the previously described methods were further serologically tested for the presence of Babesia canis (AFOSA
GmbH, Germany) (39 samples in total), Leishmania infantum (SNAP® Leishmania Test; IDEXX) (17 samples in total) and Dirofilaria immitis (SNAP® 4Dx Plus; IDEXX) (29 samples in total). All laboratory testing was performed in the Parasitology Laboratory of the Veterinary Faculty, the University of Sarajevo, which holds BAS EN ISO/IEC 17025:2006 accreditation.

The determination of parasite species was based on the assessment of morphological characteristics and measurements observed in specimens under light microscope $\mathrm{CH} 20$ BIMF200 ${ }^{\circledR}$ (Olympus) and fluorescence microscope BH-2-RFCA $\AA$ (Olympus) according to parameters specified in the diagnostic method manuals $(9,11)$.

Statistical analysis was performed using Minitab ${ }^{\circledR} 17$ statistical Software (Minitab Inc., USA). Groups with sample sizes $\geq 30$ were compared by chi-square test with Yates continuity correction. Fisher exact test was employed for comparison of groups with sample size $\leq 30$. Comparisons with $\mathrm{p}<0.05$ were considered as statistically significant.

\section{RESULTS}

Parasitic infections (positive finding for one or more parasites) were confirmed in 175 out of 212 investigated dogs $(82.55 \%)$. Twenty parasite species were isolated from all samples. Frequencies of parasitic infection on individual and group level including specific proportions of parasitic infection by group and species of parasites are shown in Table 1. Leishmania infantum was not found even though selected samples were tested for its presence. Significant differences were found between owned and stray dogs for the presence of T. canis, U. stenocephala, T. vulpis, G. duodenalis and Cryptosporidium spp. (Table 1). Significant differences between owned and stray dogs were found for Cestoda, but no such difference was found when comparing the frequency of infection for each Cestoda species.

Parasitic infection was found in 64 out of 67 dogs in the age group $\leq 6$ months, and in 111 out of 145 dogs in the age group $>6$ months. Significant differences were observed in the age group comparison (Table 2). Significant differences were found between the age groups for positive findings of Nematoda and Protozoa, more specifically for T. canis, U. stenocephala T. vulpis and G. duodenalis (Table 2). 
Table 1. Absolute (n) and relative (\%) frequency of parasites in pet and stray dogs

\begin{tabular}{|c|c|c|c|c|c|c|c|}
\hline \multirow{2}{*}{ PARASITES } & \multicolumn{2}{|c|}{$\begin{array}{l}\text { Owned dogs } \\
(n=107)\end{array}$} & \multicolumn{2}{|c|}{$\begin{array}{l}\text { Stray dogs } \\
(\mathrm{n}=105)\end{array}$} & \multicolumn{2}{|c|}{$\begin{array}{c}\text { Total } \\
(\mathrm{n}=\mathbf{2 1 2})\end{array}$} & \multirow{2}{*}{$\begin{array}{c}\text { Yates' p } \\
\text { (pet vs. } \\
\text { stray) }\end{array}$} \\
\hline & $\mathbf{n}$ & $\%$ & $\mathbf{n}$ & $\%$ & $\mathbf{n}$ & $\%$ & \\
\hline $\begin{array}{l}\text { Trematoda } \\
\text { Dicrocoelium dendriticum }\end{array}$ & 1 & 0.93 & 1 & 0.95 & 2 & 0.94 & 0.486 \\
\hline Cestoda & 9 & 8.41 & 21 & 20.00 & 30 & 14.15 & $0.026^{*}$ \\
\hline Dipylidium caninum & 4 & 3.74 & 12 & 11.43 & 16 & 7.55 & 0.063 \\
\hline Mesocestoides lineatus & 1 & 0.93 & 1 & 0.95 & 2 & 0.94 & 0.486 \\
\hline Taeniidae & 5 & 4.67 & 8 & 7.62 & 13 & 6.13 & 0.544 \\
\hline Taenia spp. & - & - & 1 & 0.95 & 1 & 0.47 & 1.000 \\
\hline Echinococcus spp. & 1 & 0.93 & 1 & 0.95 & 2 & 0.94 & 0.486 \\
\hline Nematoda & 62 & 57.94 & 86 & 81.90 & 148 & 69.81 & $<0.001^{*}$ \\
\hline Toxocara canis & 16 & 14.95 & 39 & 37.14 & 55 & 25.94 & $<0.001^{*}$ \\
\hline Toxascaris leonina & 11 & 10.28 & 8 & 7.62 & 19 & 8.96 & 0.661 \\
\hline Strongyloides stercoralis & - & - & 1 & 0.95 & 1 & 0.47 & 1.000 \\
\hline Ancylostoma caninum & 3 & 2.80 & 5 & 4.76 & 8 & 3.77 & 0.699 \\
\hline Uncinaria stenocephala & 46 & 42.99 & 65 & 61.90 & 111 & 52.36 & $0.009^{*}$ \\
\hline Trichuris vulpis & 9 & 8.41 & 38 & 36.19 & 47 & 22.17 & $<0.001^{*}$ \\
\hline Eucoleus aerophilus & 1 & 0.93 & 2 & 1.90 & 3 & 1.42 & 1.000 \\
\hline Dirofilaria immitis & 1 & 0.93 & 3 & 2.86 & 4 & 1.89 & 0.601 \\
\hline Dirofilaria repens & 2 & 1.87 & 1 & 0.95 & 3 & 1.42 & 1.000 \\
\hline $\begin{array}{l}\text { Protozoa (Classes Sporozoea and } \\
\text { Zoomastigophorea) }\end{array}$ & 11 & 10.28 & 37 & 35.24 & 48 & 22.64 & $<0.001 *$ \\
\hline Cystoisospora canis & 6 & 5.61 & 12 & 11.43 & 18 & 8.49 & 0.203 \\
\hline Cystoisospora ohioensis & 1 & 0.93 & 4 & 3.81 & 5 & 2.36 & 0.354 \\
\hline Cryptosporidium spp. & 1 & 0.93 & 9 & 8.57 & 10 & 4.72 & $0.022 *$ \\
\hline Sarcocystis spp. & - & - & 1 & 0.95 & 1 & 0.47 & 1.000 \\
\hline Babesia spp. & 8 & 7.48 & 3 & 2.86 & 11 & 5.19 & 0.228 \\
\hline Giardia duodenalis & 7 & 6.54 & 26 & 24.76 & 33 & 15.57 & $0.001 *$ \\
\hline Total & 80 & 74.77 & 95 & 90.48 & 175 & 82.55 & $0.005^{*}$ \\
\hline
\end{tabular}

*statistically significant difference 
Table 2. Absolute (n) and relative (\%) frequency of parasites in dogs less or equal 6 months of age and older than 6 months

\begin{tabular}{|c|c|c|c|c|c|}
\hline \multirow{2}{*}{ PARASITES } & \multicolumn{2}{|c|}{$\leq 6$ months $(n=67)$} & \multicolumn{2}{|c|}{$>6$ months $(n=145)$} & \multirow{2}{*}{$\begin{array}{r}\text { Yates'p } \\
(\leq 6 \text { vs }>6)\end{array}$} \\
\hline & $\mathbf{n}$ & $\%$ & $\mathbf{n}$ & $\%$ & \\
\hline $\begin{array}{l}\text { Trematoda } \\
\text { Dicrocoelium dendriticum }\end{array}$ & 1 & 1.49 & 1 & 0.69 & 0.839 \\
\hline Cestoda & 9 & 13.43 & 21 & 14.48 & 1.000 \\
\hline Dipylidium caninum & 3 & 4.48 & 13 & 8.97 & 0.384 \\
\hline Mesocestoides lineatus & 1 & 1.49 & 1 & 0.69 & 0.839 \\
\hline Taeniidae & 4 & 5.97 & 9 & 6.21 & 0.809 \\
\hline Taenia spp. & - & - & 1 & 0.69 & 0.692 \\
\hline Echinococcus spp. & 1 & 1.49 & 1 & 0.69 & 0.839 \\
\hline Nematoda & 56 & 83.58 & 92 & 63.45 & $0.005^{*}$ \\
\hline Toxocara canis & 24 & 35.82 & 31 & 21.38 & $0.039^{*}$ \\
\hline Toxascaris leonina & 8 & 11.94 & 11 & 7.59 & 0.439 \\
\hline Strongyloides stercoralis & - & - & 1 & 0.69 & 0.692 \\
\hline Ancylostoma caninum & 4 & 5.97 & 4 & 2.76 & 0.451 \\
\hline Uncinaria stenocephala & 43 & 64.18 & 68 & 46.90 & $0.028 *$ \\
\hline Trichuris vulpis & 30 & 44.78 & 17 & 11.72 & $<0.001 *$ \\
\hline Eucoleus aerophilus & 1 & 1.49 & 2 & 1.38 & 0.575 \\
\hline Dirofilaria immitis & 3 & 4.48 & 1 & 0.69 & 0.179 \\
\hline Dirofilaria repens & 1 & 1.49 & 2 & 1.38 & 0.575 \\
\hline $\begin{array}{l}\text { Protozoa (Classes Sporozoea and } \\
\text { Zoomastigophorea) }\end{array}$ & 23 & 34.33 & 25 & 17.24 & $0.009^{*}$ \\
\hline Cystoisospora canis & 9 & 13.43 & 9 & 6.21 & 0.136 \\
\hline Cystoisospora ohioensis & 3 & 4.48 & 2 & 1.38 & 0.370 \\
\hline Cryptosporidium spp. & 5 & 7.46 & 5 & 3.45 & 0.351 \\
\hline Sarcocystis spp. & - & - & 1 & 0.69 & 0.692 \\
\hline Babesia spp. & 4 & 5.97 & 7 & 4.83 & 1.000 \\
\hline Giardia duodenalis & 16 & 23.88 & 17 & 11.72 & $0.039^{*}$ \\
\hline Total & 64 & 95.52 & 111 & 76.55 & $0.001 *$ \\
\hline
\end{tabular}

*statistically significant difference 
In the owned dogs group $(n=107), 22$ were in the age category $\leq 6$ months with 19 being positive for a parasitic infection. In the same group, 85 were in the age category $>6$ months, with 61 positive for a parasitic infection. Significant differences were found between the age categories for Protozoa parasites $(\mathrm{p}=0.011)$, more specifically G. duodenalis $(\mathrm{p}=0.046)$, C. canis $(\mathrm{p}=0.018)$ and T. canis $(\mathrm{p}=0.005)$.

In the stray dogs' group ( $\mathrm{n}=105)$, all 45 dogs in the age category $\leq 6$ months and 50 out of 60 in the age category $>6$ months, were found with one or more parasite species. Significant differences were found between the age categories in this group for parasitic infection $(\mathrm{p}=0.011)$, and specifically for U. stenocephala $(\mathrm{p}=0.028)$ and T. vulpis $(\mathrm{p}<0.001)$.

There was no significant difference between positive male $(86.73 \%)$ and female dogs $(77.78 \%)$. However, when comparing sex categories for specific parasite species significant differences were revealed for Nematoda $(\mathrm{p}<0.001)$, T. canis $(\mathrm{p}=0.012)$ and $G$. duodenalis $(\mathrm{p}=0.032)$.

For the stray dogs' group, significant differences were found between positive males and females on D. caninum $(\mathrm{p}=0.041)$ and $U$. stenocephala $(\mathrm{p}=0.044)$.

\section{DISCUSSION}

Zoonotic parasites, particularly helminths and protozoa, are frequently reported $(1,12,13,14$, $15,16,17,18)$. The current study conveyed in $\mathrm{BiH}$ (Bosnian-Podrinje canton) reported the presence of various parasite species in dogs with the highest reported occurence in owned dogs. The determined exposure to parasitic infection surpasses findings in similar research reports for stray dogs from different areas in Italy: 43.02-57.41\% (14); $28.16-57.41 \%$ (25); 31.0-57.0\% (19); 28.4-35.3\% (18) and $69.1 \%$ (16).

The current study revealed a significantly larger number of younger dogs ( $\leq 6$ months) infected with G. duodenalis, T. canis and C. canis which coincides with the reports of Klarić et al. (20) and Xhaxhiu et al. (13). Significant differences between the age categories were specifically found for stray dogs for U. stenocephala and T. vulpis. Nevertheless, some parasites (Ancylostomatidae and T. vulpis) could be occasionally found in older dogs (21).

In general, a higher number of male dogs were infected by various types of parasites compared to females. A significantly higher number of male dogs were found for $T$. canis and $G$. duodenalis especially in the older age category ( $>6$ months). Other frequently reported parasite species in male dogs are T. canis, D. caninum, Ancylostoma spp., T. hydatigena and G. duodenalis (13).

Dicrocoelium dendriticum which is frequently found in ruminants was detected in dogs of this as well as another study (22).

All parasite species from the class of Cestoda confirmed by this study are zoonotic and commonly found in dogs in $\mathrm{BiH}(4,23)$. Zoonotic parasites of the genus Echinococcus are of high public health importance because the developing forms are highly resistant to environmental factors and are continuously shed by the dogs. Moreover, different parasite species (dog tapeworms) can exert various zoonotic potential $(1,2,12,13,14,15$, 17). Therefore, it is essential to include molecular methods for specific parasite identification along with the standard methods (coprology).

The positive samples were most frequently diagnosed with Nematoda. This finding is compliant with other studies, especially those including stray dogs $(5,6)$. Some of the intestinal (T. canis, T. leonina, S. stercoralis, A. caninum, U. stenocephala, T. vulpis and Capillaria spp.) and blood Nematoda species (D. immitis and D. repens) found in this study can cause disease in humans. $D$. immitis and $D$. repens are vector-borne parasites of dogs and cats which can cause severe pathological changes in animals. D. repens is considered as the main causative agent of human dirofilariasis in Europe (24). The main source are the undetected cases of dogs that commonly exhibit subclinical and fast course of the disease. The lack of reliable diagnostic tests and low public awareness of this parasite renders it with high public health importance in endemic areas (24). Numerous studies have also confirmed the increased occurrence of dirofilariasis in dogs $(3,24,25)$, including $\mathrm{BiH}$ $(26,27)$. Vector-borne helminths are becoming more frequent in humans due to increased vector transmission. The risk of exposure in humans and pets is estimated at $45.0 \%$ in Europe (3). The current study revealed that $D$. immitis is more frequently found in stray dogs, while D. repens in pet dogs. In other Mediterranean countries, the prevalence of D. immitis surpasses that of $D$. repens $(24,28)$, whereas studies in Germany and Romania report D. repens as more prevalent $(29,30)$.

We found 6 Protozoa species, of which G. duodenalis and Cryptosporidium spp. were more common in stray dogs. Recent parasitological 
studies conducted in $\mathrm{BiH}$ report findings of these parasites $(7,8,20)$. G. duodenalis (sin. G. intestinalis, G. lamblia) is an intestinal parasite found in humans and many other mammals. Dogs are infected with host-specific genotypes ( $\mathrm{C}$ and D), but there are numerous evidence that they can also carry human-specific genotypes (31). On the other hand, humans can be infected with genotype C (32). Hence, our finding of $G$. duodenalis in dogs has to be considered from the zoonotic perspective, especially due to the relatively high number of positive dogs from the younger age category. Prevalence of Giardia spp. in dogs reported by other authors ranges from $2.0 \%$ to $51.6 \%(2,12,14,15$, $16,17,21,31)$. Our finding of Cryptosporidium spp. is in agreement with other studies where the prevalence of Cryptosporidium spp. infection in dogs does not exceed 10\% $(16,22)$.

Earlier parasitological studies in $\mathrm{BiH}$ have frequently reported endoparasites of the genus Cystoisospora in dogs, especially up to 6 months of age, which is confirmed by this study $(6,7,20)$. Even though some of the found species (C. canis and $C$. ohioensis) are not zoonotic they can result in severe intestinal dysfunction in dogs. These parasites are commonly reported in studies with dogs outside of $\mathrm{BiH}(2,13,14,15,16,17,22)$.

Species of the genus Sarcocystis are zoonotic parasites that form cysts in muscles and nervous tissue of intermediate hosts (usually herbivores). In the final hosts (carnivores) they are located in the epithelium, blood vessels endothelium, muscles and other tissues. This study determined a low frequency of Sarcocystis spp. only in stray dogs which is compliant with reports by other researchers from $\mathrm{BiH}(4,7,21)$. Sarcocystis spp. finding in dogs is not uncommon, with a reported prevalence ranging from $0.6 \%$ to $9 \%$, depending on the traditional habits in feeding $(2,13,16,17,22)$.

Babesiosis has increased attention in Europe, especially for several species (B. canis canis, $B$. canis vogeli, B. gibsoni and B. microti). Its microti-like isolates are also referred to as "B. vulpes" and "Theileria" (33). Earlier studies in $\mathrm{BiH}$ have reported the finding of babesiosis in dogs in varying frequency $(7,23)$. A report using molecular identification confirmed the presence of $B$. canis in all tested samples (34). The finding of B. canis canis, B. canis vogeli and some other Babesia species in the neighboring countries and the region could implicate their presence in $\mathrm{BiH}$ $(35,36)$.

\section{CONCLUSION}

Our study found that parasitic infections of dogs are very common and that most of the parasite species are zoonotic. The control and monitoring of zoonotic parasite infections in dogs as well as raising public awareness can reduce the prevalence both in humans and animals. Ontime and appropriate diagnosis, regular prophylactic treatment, sanitary improvements in pet public areas must be enforced by appropriate regulations. The uncontrolled vector populations and wildlife can render increased vector-borne transmission in endemic areas. This is why an interdisciplinary and integrated approach (i.e. One Health) is necessary for the efficient control of parasitic diseases as a global public health issue.

\section{CONFLICT OF INTEREST}

The authors declared that they have no potential conflict of interest with respect to the authorship and/or publication of this article.

\section{ACKNOWLEDGEMENTS}

This study was conducted under the Department for Parasitology and Invasive Diseases in Animals at the Veterinary Faculty University of Sarajevo in cooperation with veterinary practices and animal shelter from Bosnian-podrinje canton.

\section{AUTHORS' CONTRIBUTIONS}

JO and ĆC conceived/designed the study. EA, NK, DKS, EŠ and AĆ performed the research. JO, ĆC, SSH and DA analized the data. JO, VŠ, DŽHA and SSH wrote the manuscript. JO and SSH revised the manuscript and approved it for publishing.

\section{REFERENCES}

1. Dantas-Torres, F., Otranto, D. (2014). Dogs, cats, parasites, and humans in Brazil: opening the black box. Parasites Vectors 7, 22.

https://doi.org/10.1186/1756-3305-7-22

PMid:24423244 PMCid:PMC3914713

2. Barutzki, D., Schaper, R. (2011). Results of parasitological examinations of faecal samples from cats and dogs in Germany between 2003 and 2010. Parasitol Res. 109 (Suppl 1), 45-60. https://doi.org/10.1007/s00436-011-2402-8 PMid:21739375 
3. Otranto, D., Dantas-Torres, F., Brianti, E., Traversa, D., Petrić, D., Genchi, C., Capelli, G. (2013). Vectorborne helminths of dogs and humans in Europe. Parasites Vectors 6, 16. https://doi.org/10.1186/1756-3305-6-16 PMid:23324440 PMCid:PMC3564894

4. Esko, S. (1994). Endoparasites dogs in Sarajevo and their importance in the war environment of the city. Doctoral disertation, University of Sarajevo [in Bosnian]

5. Omeragić, J., Jažić, A., Zuko, A. et al. (1998). The results of coprological tests for developing forms of endoparasites on dogs and cats in the Sarajevo region for the years 1997-1998. Veterinaria 47(1-2).

6. Omeragić, J. (2002). Investigation of Toxocarosis in the area of the Herzegovina. Master thesis, University of Sarajevo [in Bosnian]

7. Hrvat, H. (2015). Investigation of protozoa from the class of Sporozoea and Zoomastigophorea of dogs in area of northeast Bosnia. Thesis, University of Sarajevo [in Bosnian]

8. Klarić Soldo, D., Omeragić, J., Zuko, A. et al. (2019). Investigation of parasites in dogs and cats and contamination of soil and plant vegetation with parasites in the area of the City of Sarajevo. Veterinaria 68, 115-119.

9. Zajac, A.M., Conboy, G. (2012). Veterinary clinical parasitology. 8th ed. Oxford: Wiley-Blackwell Publishing

10. Johnston, S.P., Ballard, M.M., Beach, M.J., Causer, L., Wilkins, P.P. (2003). Evaluation of three commercial assays for detection of Giardia and Cryptosporidium organisms in fecal specimens. J Clin Microbiol. 41,623-626.

https://doi.org/10.1128/JCM.41.2.623-626.2003

PMid:12574257 PMCid:PMC149727

11. Thienpont, D., Rochette, F., Vanparijs, O.F.J. (1979). Diagnosing helminthiasis trough coprological examination. Beerse: Janssen Research Foundation

12. Nikolić, A., Dimitrijević, S., Katić-Radivojević, S., Klun, I., Bobić, B., Djurković-Djaković, O. (2008). High prevalence of intestinal zoonotic parasites in dogs from Belgrade, Serbia. Acta Vet Hung. 56, 335-340. https://doi.org/10.1556/avet.56.2008.3.7 PMid:18828485

13. Xhaxhiu, D., Kusi, I., Rapti, D., Kondi, E., Postoli, R., Rinaldi, L., Dimitrova, Z.M., Visser, M., Knaus, M., Rehbein, S. (2011). Principal intestinal parasites of dogs in Tirana, Albania. Parasitol Res. 108, 341-353. https://doi.org/10.1007/s00436-010-2067-8 PMid:20878182
14. Riggio, F., Mannella, R., Ariti, G., Perrucci, S. (2013). Intestinal and lung parasites in owned dogs and cats from central Italy. Vet Parasitol. 193, 78-84. https://doi.org/10.1016/j.vetpar.2012.11.026 PMid:23265188

15. Zanzani, S.A., Gazzonis, A.L., Scarpa, P., Berrilli, F., Manfredi, M.T. (2014). Intestinal parasites of owned dogs and cats from metropolitan and micropolitan areas: prevalence, zoonotic risks, and pet owner awareness in northern Italy. Biomed Res Int. 2014, 696508.

https://doi.org/10.1155/2014/696508

PMid:24883320 PMCid:PMC4022196

16. Ferreira, A., Margarida-Alho, A., Otero, D., Gomes, L., Nijsse, R., Overgaauw, P.A.M., Madeira de Carvalho, L. (2017). Urban dog parks as sources of canine parasites: contamination rates and pet owner behaviours in Lisbon, Journal of Environmental and Public Health 7, 5984086.

https://doi.org/10.1155/2017/5984086

PMid:28947905 PMCid:PMC5602491

17. De Liberato, C., Berrilli, F., Odorizi, L., Scarcella, R., Barni, M., Amoruso, C., Scarito, A., et al. (2018). Parasites in stray dogs from Italy: prevalence, risk factors and management concerns. Acta Parasitol. $63,27-32$.

https://doi.org/10.1515/ap-2018-0003

PMid:29351076

18. Scaramozzino, P., Carvelli, A., Iacoponi, F., De Liberato, C. (2018). Endoparasites in household and shelter dogs from Central Italy. IJVS. 6, 45-47. https://doi.org/10.1016/j.ijvsm.2018.04.003 PMid:30255077 PMCid:PMC6148681

19. Paoletti, B., Traversa, D., Iorio, R., De Berardinis, A., Bartolini, R., Salini, R., Di Cesare A. (2015). Zoonotic parasites in feces and fur of stray and private dogs from Italy. Parasitol Res. 114, 2135-2141. https://doi.org/10.1007/s00436-015-4402-6 PMid:25773179

20. Klarić, D., Radetić, V., Gajić, N., Cviko, A., Grabovica, E., Smajlović, A., Crnkić, Ć., Omeragić, J. (2015). Control of parasites in the kennel of Belgian shepherd dog. Abstract book, International Congress "One World - One Health - One Vision", October 14-16 (pp.28), Sarajevo, Bosnia and Herzegovina

21. Bartosik, J., Lojek, J., Puchala, M., Kaczyk, J., Górski, P., Długosz, E., Zygner, W. (2019). Prevalence of intestinal parasites detected in routine coproscopic methods in dogs and cats from the Masovian voivodeship in 2012-2015. Med Weter. 75, 293-297. https://doi.org/10.21521/mw.6153 
22. Kohansal, M.H., Fazaeli, A., Nourian, A., Haniloo, A., Kamali, K. (2017). Dogs' gastrointestinal parasites and their association with public health in Iran. J Vet Res. 61, 189-195.

https://doi.org/10.1515/jvetres-2017-0024

PMid:29978072 PMCid:PMC5894391

23. Omeragić, J., Zuko, A., Jažić, A. et al. (2002). Tick borne babesiosis of dogs in Bosnia and Herzegovina. Proceedings, 27th World Veterinary Congress, September 25-29, Tunis, Tunisia.

24. Capelli, G., Genchi, C., Baneth, G., Bourdeau, P., Brianti, E., Cardoso, L., Danesi, P., et al. (2018). Recent advances on Dirofilaria repens in dogs and humans in Europe. Parasites Vectors 11, 663. https://doi.org/10.1186/s13071-018-3205-x PMid:30567586 PMCid:PMC6299983

25. Genchi, C., Rinaldi, L., Mortarino, M., Genchi, M., Cringoli, G. (2009). Climate and Dirofilaria infection in Europe. Vet Parasitol. 163, 286-292. https://doi.org/10.1016/j.vetpar.2009.03.026 PMid:19398159

26. Zahirović, A., Omeragić, J., Jažić, A. et al. (2015). The occurrence and geographical distribution of canine dirofilariasis in Bosnia and Herzegovina. The 2nd Conference on neglected vectors and vector-borne diseases (EURNEGVEC), May 24-26, Izmir, Turkey.

27. Omeragić, J., Beck, R., Klarić, D., Bačić E. (2018). Dirofilaria repens in canine testicles in Bosnia and Herzegovina. Veterinaria 67(1): 37-40.

28. Jurković, D., Beck, A., Huber, D., Mihaljević, Ž., Polkinghorne, A., Martinković, F., Lukačević, D., et al. (2019). Seroprevalence of vector-borne pathogens in dogs from Croatia. Parasitol Res. 118, 347-352. https://doi.org/10.1007/s00436-018-6129-7 PMid:30377795

29. Pantchev, N., Norden, N., Lorentzen, L., Rossi, M., Rossi, U., Brand, B., Dyachenko, V. (2009). Current surveys on the prevalence and distribution of Dirofilaria spp. in dogs in Germany. Parasitol Res. 105,63

https://doi.org/10.1007/s00436-009-1497-7 PMid:19575227
30. Genchi, C., Kramer, L. (2017). Subcutaneous dirofilariosis (Dirofilaria repens): an infection spreading throughout the old world. Parasites Vectors 10 (Suppl 2), 517.

https://doi.org/10.1186/s13071-017-2434-8

PMid:29143643 PMCid:PMC5688444

31. Solarczyk, P., Majewska, C.A. (2010). A survey of the prevalence and genotypes of Giardia duodenalis infecting household and sheltered dogs. Parasitol Res. 106, 1015-1019.

https://doi.org/10.1007/s00436-010-1766-5

PMid:20155370

32. Strkolcova, G., Madar, M., Hinney, B., Goldová, M., Mojžišová, J., Halánová, M. (2015). Dog’s genotype of Giardia duodenalis in human: first evidence in Europe. Acta Parasitol. 60, 796-799.

https://doi.org/10.1515/ap-2015-0113

PMid:26408607

33. Solano-Gallego, L., Sainz, Á., Roura, X., Miro, G. (2016). A review of canine babesiosis: the European perspective. Parasites \& Vectors 9, 336.

https://doi.org/10.1186/s13071-016-1596-0

PMid:27289223 PMCid:PMC4902949

34. Ćoralić, A., Gabrielli, S., Zahirović, A., Stojanović, N.M., Milardi, G.L., Jažić, A., Zuko, A., et al. (2018). First molecular detection of Babesia canis in dogs from Bosnia and Herzegovina. Ticks Tick Borne Diseases 9, 363-368.

https://doi.org/10.1016/j.ttbdis.2017.11.013 PMid:29290581

35. Duh, D., Tozon, N., Petrovec, M., Straseka, K., Avsic-Zupanc, T. (2004). Canine babesiosis in Slovenia: molecular evidence of Babesia canis canis and Babesia canis vogeli. Vet Res. 35, 363-368.

https://doi.org/10.1051/vetres:2004018

PMid:15210084

36. Hamel, D., Silaghi, C., Knaus, M., Visser, M., Kusi, I., Rapti, D., Rehbein, S., Pfister, K. (2009). Detection of Babesia canis subspecies and other arthropod-borne diseases in dogs from Tirana, Albania. Wien Klin Wochenschr. 121, 42-45. https://doi.org/10.1007/s00508-009-1234-3 PMid:19915816 